\title{
TUNNELING IN OPHIOLITHIC SERIES FORMATIONS: TUNNELS OF THE NEW HIGH-SPEED RAILWAY DOUBLE TRACK LINE - SECTION LIANOKLADI - DOMOKOS
}

\author{
Mourtzas N. ${ }^{1}$ and Gkiolas A. ${ }^{2}$ \\ ${ }^{1}$ Geologist PhD, Gaiaergon Geotechnical Firm., Kefallinias 16-18, 15231 Athens, Greece, \\ gaiaergon@gmail.com \\ ${ }^{2}$ Civil Engineer, PhD, Geomechaniki S.A,Ethnikis Antistaseos 91,15351 Pallini, Greece \\ geomsot@gmail.com.
}

\begin{abstract}
For the project "3rd phase of design of the new high speed double track line - section LianokladiDomokos (subsection: Ch. 0+000 - Ch. 13+500)" geological and geotechnical investigations and designs were implemented for tunnels and cut \& cover of the subsection Ch.9+685-Ch. 12+254. The above subsection, a significant part of which is already constructed, includes three tunnels (SSI, SS2 and SS4) and one Cut \& Cover (SS3). Tunnels SS1, SS2 and SS4 are of lengths 860m, 477m and $495 \mathrm{~m}$, with overburden $58 \mathrm{~m}$, 50m and $60 \mathrm{~m}$ respectively and are driven in mountainous area consisting of ophiolithic series formations, mainly massive basalts with varying fragmentation, dolerites, spilitic intrusions and serpentinites. The above formations are characterised by variable fragmentation, weathering and degree of alteration. At places metamorphic basalt (amphibolite) is also encountered. Schist-chert intrusions and ophiolithic material with intense schistification, are considered of tectonic origin and are connected with the major and secondary compressive fault zone in the area. Limestone blocks inside the ophiolithic mass are also considered of tectonic origin. The narrow area of the alignment is characterized by the presence of normal and transverse faults, along with major joints crossing the rockmass. The formations along the tunnels, according to their engineering - geological behaviour, were separated to seven geotechnical units. Representative values for the geotechnical parameters of each unit were determined and analyses for the corresponding primary support categories were performed, using code UNWEDGE (RocScience) for rock-classes were behaviour of underground excavation is determined mainly due to orientation of joints and using code PHASE version 6.011(RocScience) for formations were behaviour of underground excavation is determined mainly by their strength and deformability.
\end{abstract}

Key words: ophiolites, compressive fault zone, high speed double track line, tunnel, Central Greece.

\section{Introduction - Project Description - Tunnel Excavation Geometry}

For the project " 3 rd phase of design of the new high speed double track line - section Lianokladi Domokos (subsection: Ch. 0+000 - Ch. 13+500)" geological and geotechnical investigations and designs were implemented for tunnels and cut \& cover of the subsection Ch. $9+685$ - Ch. $12+254$. The above subsection, a significant part of which is already constructed, includes three tunnels SS1, SS2 and SS4 (Fig. 1). 


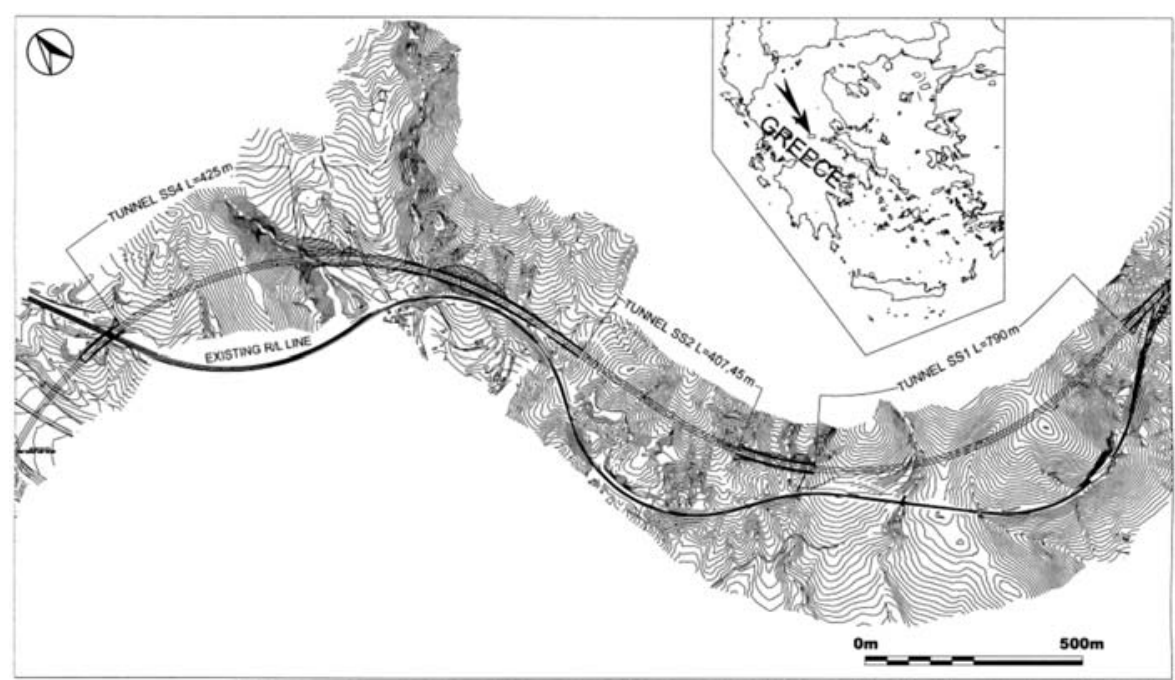

Fig. 1: Location map of the project area.

Tunnel SS1 is of length $860 \mathrm{~m}$, with maximum overburden of $58 \mathrm{~m}$. The alignment passes with a high radius curve. The tunnel axis trend is E-SE to W-NW, with a longitudinal slope of $2 \%$. Tunnel SS2 is of length $477 \mathrm{~m}$, with maximum overburden of $50 \mathrm{~m}$. The alignment passes with a high radius curve. The tunnel axis trend is NW to SE, with a longitudinal slope of $1.84 \%$. Tunnel SS4 is of length $495 \mathrm{~m}$, with maximum overburden of $60 \mathrm{~m}$. The alignment passes with a high radius curve. The tunnel axis trend is E-SE to W-NW, with a longitudinal slope of $1.84 \%$

Geometry of the tunnels is horseshoe shaped and excavation takes place in two phases: upper and lower bench. In adverse ground conditions, upper bench (temporary) and lower bench inverts are also constructed. The excavated section width is of approximately $14 \mathrm{~m}$.

\section{Geological setting}

The project area extends on the southern margin of the Othrys Mountain chain where the geological structure is characterized by a series of nappes, placed on top the Pelagonic platform during Upper Jurassic - Lower Cretaceous (Hynes 1974).

The higher nappe includes typical ophiolithic rocks (peridotites, gabbros, dolerites, pillow lavas), while the lower one is constituted by Volcano-Sedimentary formations. On top of the nappes an Upper Cretaceous transgression cover has been deposited (Smith et al., 1975), while the whole sequence is found overthrusted along a westward-direction over flysch of the Upper Cretaceous - Tertiary (Faulp et al., 1996).

The geological structure of the broader area includes three tectonic nappes which constitute the rocks of the substratum and of which the lower one includes the schist-chert formation, the following includes basalts (dolerites) and the higher one peridotites. The overthrust front of the peridotitic nappe is found inside the strict area of the project.

The intense topographic relief at the tunnels area is shaped on rocks of the Ophiolithic Sequence, mainly by basalts, dolerites, spilitic intrusions and serpentinites. These formations are characterized 
by varying degrees of fragmentation, weathering and alteration.

The schist-chert intercalations and the schistified ophiolithic material are considered to be of tectonic origin and they are linked mainly to the primary and secondary tangential compressional structures of the area and to fault tectonics.

Extended limestone bodies which are locally found inside the ophiolithic masses are also considered of tectonic origin. This complex lithologic and tectonic structure of the area was mapped in detail on a 1:200 scale at the extended in length, high slopes of the existing railroad track, which stretch $20 \mathrm{~m}$ to $300 \mathrm{~m}$ downhill the new railroad axis.

In particular, the tunnels are expected to be drilled through:

Basalts (Dolerites), medium-grained, greenish-grey to grey, comprised mainly by pyroxenes and plagioclasts on a semi-crystalline porphyritic texture, with a varying degree of fragmentation and locally intense alterations, while inside the formation pillow lavas locally occur.

Altered Spilites: with compact fabric, characteristic intermediate texture and spharolites, intruded inside the original serpentinite rock, which in turn is fragmented and locally re-cemented mainly with clay minerals, serpentine and feldspars and secondary with quartz, chlorite and calcite.

The formation is found intensely altered, with abundance of calcite, part of which came from the alteration of plagioclasts while another is found in veinlets. The distribution of the calcite inside the rock is anisomeric. The main minerals of this occurrence are calcite, quartz and plagioclast, while secondary minerals are chlorite and iron oxides.

Limestone: with granular texture and compact fabric. The main mineral is calcite and the secondary ones are chlorite, quartz and iron oxides.

Spilite: with intermediate texture and compact fabric. It is lava of spilitic constitution, which seems to cross through and locally enclave the serpentinite. Calcite observed in veinlets and amygdules.

The rock is crossed by quartz microveins (stockwork) of heterogeneous origin, whose percentage of participation varies locally within the rock mass. The main minerals of the rock are feldspars, chlorite, serpentine and calcite, while the secondary minerals are quartz and clay minerals.

Serpentinite: with symplectic texture and compact fabric, main minerals are serpentine, talc, chlorite and plagioclasts and secondary minerals calcite and iron oxides.

The foliaceous friable formations are distinguished in

Schists-cherts with intensly foliaceous to shaly structrure, brown to purple.

Cleavaged, breccious and altered ophiolithic material: with breccias, fragments and bodies of ophiolites and limestones in its mass, intensely folded and locally with chaotic structure.

In boreholes it appears in the form of silty-clayey gravels, of ophiolithic origin, with sand or intensely fractured cherts in the form of pebbles of $0.05 \times 0.04 \times 0.03 \mathrm{~m}$ size. Locally chert layers, of $2 \mathrm{~m}$ maximum thickness, intervene, intensely to very intensely fractured.

Altered ophiolithic materials: in the form of coherent calc-clay material; whitish to yellowish.

Intensely weathered and loosened surface zones of the rocky substratum. It involves sandy clays to clayey sands, brown to brownish-grey, which include fragments and breccias of ophiolites. In boreholes they appear in the form of ophiolite fragments and pebbles, of $0.02 \times 0.01 \mathrm{~m}$ to $0.05 \times 0.3 \mathrm{~m}$ 
sizes, with locally occurring sandy clays.

The strict area of the axis is characterized by small to medium scale up-thrusting events, normal and reverse structures, as well as by major joints crossing the rock-mass.

\section{Groundwater regime}

The bedrock in the area is considered as permeable formation especially when it is intensely fragmented, fractured or intensely fractured. On the other hand schistified, friable formations are considered as impermeable formations and only in zones of intense shearing may develop a weak water table.

For tunnel SS1, based on the water level measurements from boreholes, in the initial region of the tunnel $(\mathrm{Ch} .9+685 \div \mathrm{Ch} .9+753)$ the groundwater level is expected between $6.5 \mathrm{~m}$ to $14 \mathrm{~m}$ above the tunnel redline, in the region from Ch. $9+753$ to $\mathrm{Ch}$. $10+040$, between $14 \mathrm{~m}$ to $31 \mathrm{~m}$ above the tunnel redline, in the region from Ch. $10+040$ to $\mathrm{Ch} .10+227$ between $3 \mathrm{~m}$ to $14 \mathrm{~m}$, in the region from $\mathrm{Ch}$. $10+227$ to $\mathrm{Ch} .10+433$ between $1 \mathrm{~m}$ to $1,5 \mathrm{~m}$ and in the final region of the tunnel from Ch. Ch. $10+433$ to $\mathrm{Ch} .10+475$, groundwater level is expected below the level of the tunnel.

For tunnel SS2, based on the water level measurements from boreholes in the initial region of the tunnel (Ch. $10+681$ to Ch. $10+735)$, the groundwater level is expected between $1 \mathrm{~m}$ to $9,5 \mathrm{~m}$ above the tunnel redline. In the region of the tunnel from $\mathrm{Ch} .10+735$ to $\mathrm{Ch} .11+055$ groundwater level is expected between $10 \mathrm{~m}$ to $23 \mathrm{~m}$ above the tunnel redline and in the final region of the tunnel from $\mathrm{Ch}$. $11+055$ to $\mathrm{Ch} .11+089$ between $5 \mathrm{~m}$ to $11 \mathrm{~m}$ above the tunnel redline.

For tunnel SS4, based on the water level measurements from boreholes in the initial region of the tunnel (Ch. $11+800$ to $\mathrm{Ch} .11+976)$ the groundwater level is expected between $18 \mathrm{~m}$ to $24 \mathrm{~m}$ above the tunnel redline, in the region of the tunnel from Ch. $11+976$ to $\mathrm{Ch} .12+022$ at $24 \mathrm{~m}$ and in the final region of the tunnel from Ch. $12+022$ to $\mathrm{Ch} .12+225$ between $11 \mathrm{~m}$ and $23 \mathrm{~m}$.

\section{Geotechnical Units}

The formations along the tunnels, according to their engineering - geological behavior, were separated to seven geotechnical units, as follows:

Geotechnical Unit TE-1: This unit includes massive to slightly fragmented ophiolites, of low strength, with RQD greater than 60\%, rock mass rating (RMR) between 45 and 65 (category II to III according to Bieniawski 1989) and estimated GSI ranging between 45 and 55 (according to HoekBrown, 2002)

Geotechnical Unit TE-2: This unit includes intensely fragmented ophiolites, of low strength, with RQD between $30 \%$ and $60 \%$, rock mass rating (RMR) between 35 and 45 (category III to IV according to Bieniawski 1989) and estimated GSI ranging between 35 and 45.

Geotechnical Unit TE-3: This unit includes intensely fragmented to fractured ophiolites, of low strength, with RQD between $0 \%$ and $30 \%$, rock mass rating (RMR) between 10 and 35 (category IV to V according to Bieniawski 1989) and estimated GSI ranging between 25 and 35.

Geotechnical Unit TE-4: This unit includes intensely fractured ophiolites, in the form of gravel and cobbles with sizes from $0.03 \times 0.01 \mathrm{~m}$ to $0.07 \times 0.05 \mathrm{~m}$ and rock mass rating (RMR) less than $10 \%$. Estimated GSI ranging between 20 and 25. 
Geotechnical Unit TE-5: This unit includes schistified, heavily broken and altered ophiolithic material with angular and rounded rock pieces of ophiolites and limestone, intensely folded, with a chaotic structure at places and brown to crimson almost soil-like material of the schist-chert formation with intense schistification, in $0.05 \mathrm{~m}$ to $0.02 \mathrm{~m}$ thick layers. In borehole samples, the above material appears in the form of silty-clayey gravel of ophiolithic origin, with sand, or intensely fragmented chert, in the form of gravel and cobbles with approx. size of $0.05 \times 0.04 \times 0.03 \mathrm{~m}$. At places intensely fragmented to heavily broken chert interlayers of up to $2 \mathrm{~m}$ thickness, are encountered. Estimated GSI ranging between 15 and 20.

Geotechnical Unit TE-6: This unit includes altered, mylonitized material, associated with zones of tectonic deformation. It appears in the form of sub-white to sub-yellow sand, with low cohesion. Estimated GSI ranging between 15 and 20

Geotechnical Unit TE-7: This unit includes limestone blocks, of intermediate strength, intensely folded and fractured and up to at places intensely fractured. Estimated GSI ranging between 35 and 40. The Geotechnical unit TE-7 is merely encountered in tunnel SS1.

\section{Geological- Geotechnical conditions along tunnels}

The ophiolithic mass along tunnel SS1 is separated in six regions, in tunnel SS2 in four regions and in tunnel SS4 in three regions. In the area of tunnel SS1, a total of eight continuous sampling boreholes have been executed, five in the area of tunnel SS2 and four in the area of tunnel SS4. The Geological- Geotechnical long section of tunnel SS1 is presented in Figure 2, of tunnel SS2 in Figure 3 and of tunnel SS4 in Figure 4.

Tunneling conditions along tunnels area extremely variable, ranging from favorable to adverse. The estimated percentages of Geotechnical units for the three tunnels are presented in table 1:

Table 1 Estimated percentages of Geotechnical units for the tunnels

\begin{tabular}{|c|c|c|c|c|c|c|c|c|c|}
\hline \multirow{3}{*}{ Tunnel } & \multicolumn{2}{|c|}{ Region } & \multicolumn{7}{|c|}{ Geotechnical Units Percentages (\%) } \\
\cline { 2 - 10 } & Start Ch. & End Ch. & TE-1 & TE-2 & TE-3 & TE-4 & TE-5 & TE-6 & TE-7 \\
\hline \multirow{5}{*}{ SS1 } & $9+685$ & $9+753$ & $32 \%$ & 35 & $25 \%$ & $3 \%$ & $4 \%$ & $1 \%$ & - \\
\cline { 2 - 10 } & $9+753$ & $10+040$ & - & - & $25 \%$ & $8 \%$ & $64 \%$ & $2 \%$ & $1 \%$ \\
\cline { 2 - 10 } & $10+040$ & $10+227$ & - & $22 \%$ & $35 \%$ & $7 \%$ & $5 \%$ & - & $31 \%$ \\
\cline { 2 - 10 } & $10+227$ & $10+251$ & - & $5 \%$ & $10 \%$ & $12 \%$ & $72 \%$ & - & $1 \%$ \\
\cline { 2 - 10 } & $10+251$ & $10+433$ & - & $1 \%$ & $2 \%$ & $6 \%$ & $55 \%$ & $28 \%$ & $8 \%$ \\
\cline { 2 - 10 } & $10+433$ & $10+457$ & $24 \%$ & $26 \%$ & $36 \%$ & $7 \%$ & $7 \%$ & - & - \\
\hline \multirow{5}{*}{ SS2 } & $10+681$ & $10+735$ & $1 \%$ & - & $4 \%$ & $70 \%$ & $25 \%$ & - & - \\
\cline { 2 - 10 } & $10+735$ & $10+922$ & $27 \%$ & $15 \%$ & $28 \%$ & $26 \%$ & - & $4 \%$ & - \\
\cline { 2 - 10 } & $10+922$ & $11+062$ & $19 \%$ & $30 \%$ & $42 \%$ & $3 \%$ & $6 \%$ & - & - \\
\cline { 2 - 10 } & $11+062$ & $11+089$ & - & $5 \%$ & - & $35 \%$ & $60 \%$ & - & - \\
\hline \multirow{3}{*}{ SS4 } & $11+800$ & $11+976$ & $50 \%$ & $10 \%$ & $37 \%$ & - & $2 \%$ & 1 & - \\
\cline { 2 - 9 } & $11+976$ & $12+022$ & - & - & $20 \%$ & $25 \%$ & $55 \%$ & - & - \\
\cline { 2 - 9 } & $12+022$ & $12+225$ & $18 \%$ & $35 \%$ & $36 \%$ & $5 \%$ & $1 \%$ & $5 \%$ & - \\
\hline
\end{tabular}




\section{Rockmass classes. Association with Geotechnical units}

Based on the available geological and geotechnical data and the expected behavior of the rockmass during excavation the following five rockmass classes were implemented

Rockmass class A - Massive to slightly fragmented rockmass. Rockmass class A includes massive to slightly fragmented ophiolites (TE-1) and limestone blocks, of intermediate strength, intensely folded and fractured and up to at places intensely fractured (TE-7). Stable behavior during excavation. No systematic relaxation of rock blocks and depending on the geometry of the discontinuities, possible formation of wedges. Systematic support against wedges is required. No practical impact of underground water in rockmass strength. Excavation with explosives. Representative GSI values:

TE-1: GSI $=45-55 \& T E-7: G S I=35-45$

Rockmass class B1 - Intensely fragmented rockmass: Rockmass class B1 includes intensely fragmented ophiolites, of low strength (TE-2). Relaxation of rock blocks and formation of wedges. Systematic support against wedges is required. Small impact of underground water in rockmass strength. Excavation with explosives. Representative GSI values:

TE-2: GSI $=35-45$

Rockmass class B2 - Intensely fragmented to fractured rockmass: Rockmass class B2 includes intensely fragmented to fractured ophiolites, of low strength. Increased risk of failure without installation of immediate support measures. Medium impact of underground water in rockmass strength. Excavation with mechanical means. Representative GSI values:

TE-3: GSI $=25-35$

Rockmass class C1 - Intensely fractured rockmass: Rockmass class C1 includes intensely fractured ophiolites, in the form of gravel and cobbles (TE-4). Systematically and intensely tectonised and sheared rockmass, of very low strength and intense weathering. At places soil-like material with possibility of appearance of rock boulders. Immediate deformation. Development of failure zones of reduced thickness in the sidewalls. High impact of underground water in rockmass strength. Excavation with mechanical means. Representative GSI values:

TE-4: GSI $=20-25$

Rockmass class C2 - Schistified, friable formations: Rockmass class C2 includes schistified, heavily broken and altered ophiolithic material with angular and rounded rock pieces of ophiolites and limestone, intensely folded, with a chaotic structure and soil-like material of the schist-chert formation with intense schistification, (TE-5) altered, mylonitized material, associated with zones of tectonic deformation appearing in the form of sand with low cohesion (TE-6). Systematically and intensely tectonised and sheared rockmass, of very low strength and very intense weathering. Soil-like material with possibility of appearance of rock boulders. Immediate deformation. Development of failure zones of reduced thickness in the sidewalls. High impact of underground water in the rockmass strength. Excavation with mechanical means. Representative GSI values:

$\underline{T E-5, T E-6: G S I=15-20}$

For the above rockmass classes representative values of geotechnical parameters were estimated by means of Hoek-Brown criterion (2002), and are presented in table 2. 


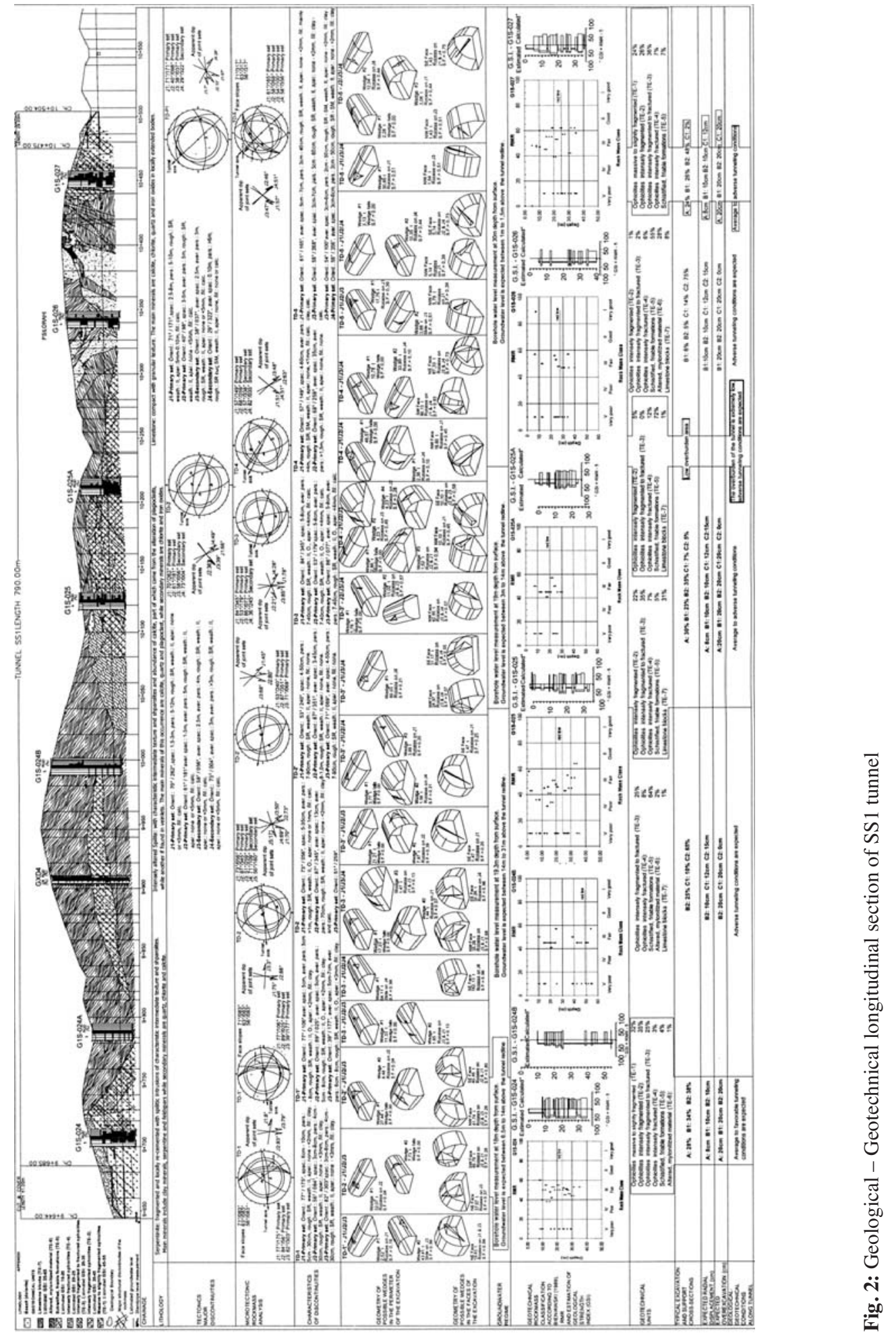




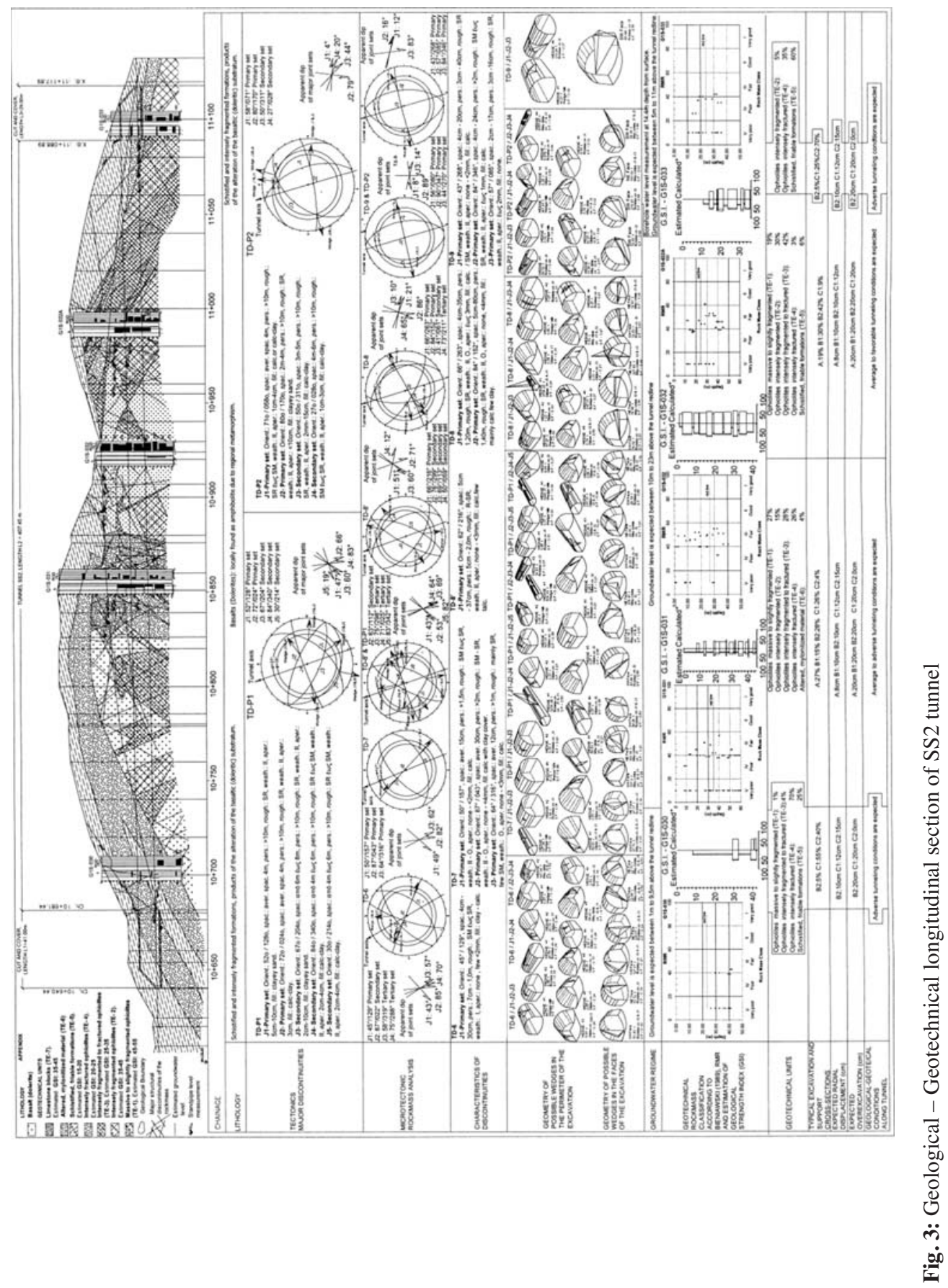




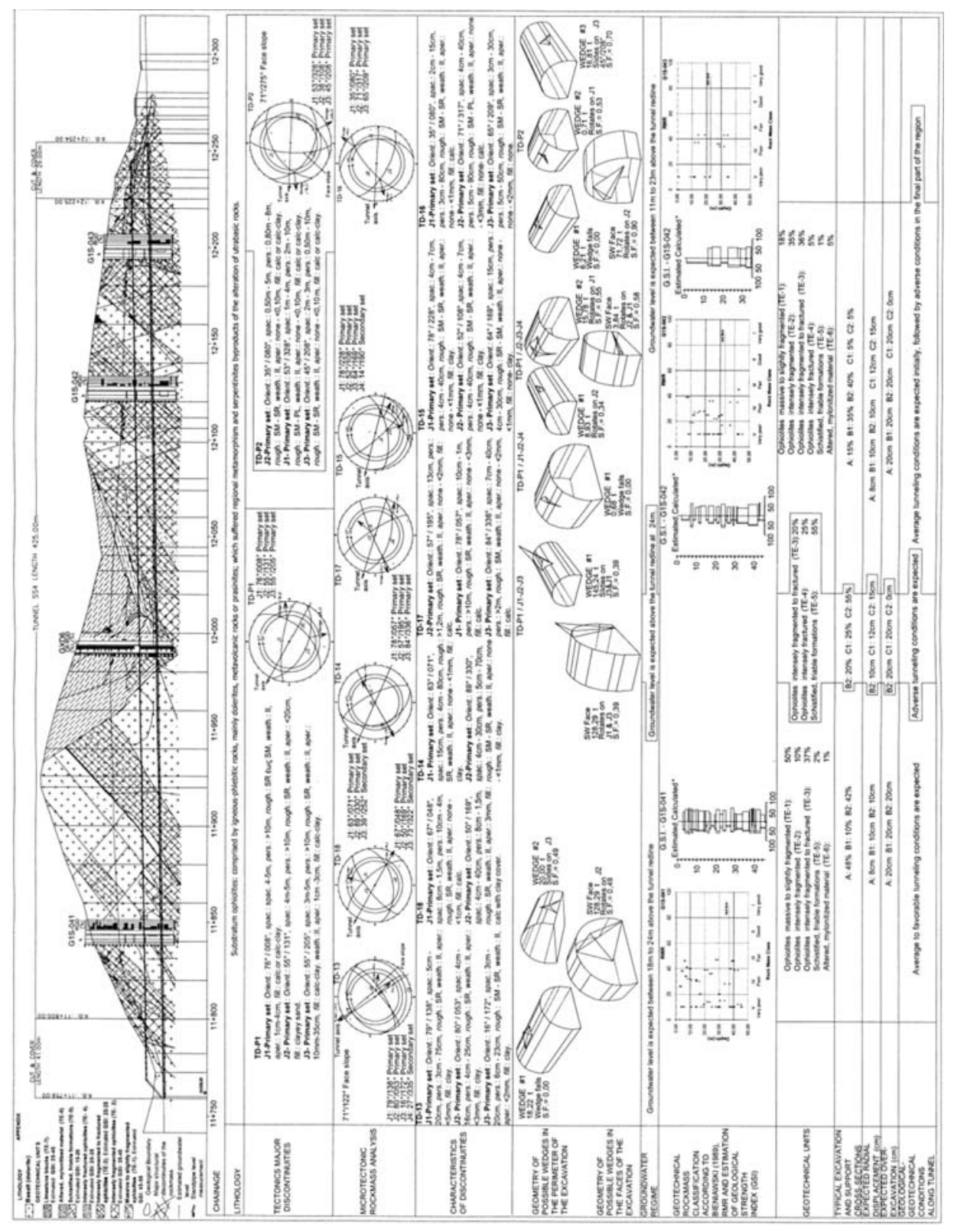

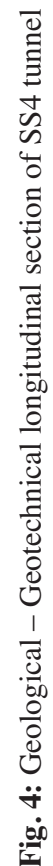


Table 2. Geotechnical design parameters

\begin{tabular}{|c|c|c|c|c|c|c|c|}
\hline $\begin{array}{c}\text { Rockmass } \\
\text { class }\end{array}$ & $\begin{array}{c}\text { Geotechnical } \\
\text { unit }\end{array}$ & GSI & $\begin{array}{c}\text { GSI } \\
\text { design) }\end{array}$ & $\begin{array}{c}\boldsymbol{\sigma}_{\mathbf{c i}} \\
(\mathbf{M P a})\end{array}$ & $\mathbf{m}_{\mathbf{i}}$ & $\begin{array}{c}\text { Overburden } \\
\mathbf{u p ~ t o ~} \mathbf{H} \\
(\mathbf{m})\end{array}$ & $\begin{array}{c}\boldsymbol{\gamma} \\
\left(\mathbf{k N} / \mathbf{m}^{3}\right)\end{array}$ \\
\hline \multirow{2}{*}{$\mathrm{A}$} & TE-1 & $45-55$ & 45 & 20 & 25 & $48 \sim 60$ & 28 \\
\cline { 2 - 7 } & TE-7 & $35-45$ & 35 & 40 & 10 & $48 \sim 60$ & 27 \\
\hline B1 & TE-2 & $35-45$ & 35 & 15 & 20 & $48 \sim 60$ & 26 \\
\hline B2 & TE-3 & $25-35$ & 25 & 12 & 20 & $48 \sim 60$ & 26 \\
\hline C1 & TE-4 & $20-25$ & 20 & 7 & 15 & $48 \sim 60$ & 22 \\
\hline C2 & TE-5, TE-6 & $15-20$ & 15 & 5 & 15 & $48 \sim 60$ & 22 \\
\hline
\end{tabular}

Table 3. Typical excavation and support cross-sections - Association with rockmass classes and geotechnical units

\begin{tabular}{|c|c|c|}
\hline Rockmass class & Geotechnical unit & $\begin{array}{c}\text { Typical excavation and } \\
\text { support cross-sections }\end{array}$ \\
\hline A & TE-1, TE-7 & A \\
\hline B1 & TE-2 & B1 \\
\hline B2 & TE-3 & B2 \\
\hline C1 & TE-4 & C1 \\
\hline C2 & TE-5,TE-6 & C2 \\
\hline
\end{tabular}

Based on the above design parameters, analyses for the dimensioning of the typical excavation and support cross-sections were performed.

\section{Typical excavation and support cross-sections}

For the five rockmass classes, five corresponding typical excavation and support cross-sections were implemented for the tunnels. The typical excavation and support cross-sections are presented in figures 5 and 6.

Their association with rockmass classes and geotechnical units is presented in table 3 .

The predominant factor affecting the behavior of the underground excavation for rockmass class A, is the orientation of intersecting structural discontinuities and on the other hand for rockmass classes $\mathrm{C} 1$ and $\mathrm{C} 2$ is the structural behavior of the rockmass for the expected range of values of in-situ stress, rockmass strength and deformability parameters. For rockmass classes B1 and B2, both factors are important.

For rockmass classes B1, B2, C1, C2, finite element stress analyses were performed for the developed excavation and support models. For the calculation of induced stress on the immediate support elements and for the estimation of tunnel wall convergence and thickness of yield zone in the rockmass, computer code PHASE² ver 6.011 (developed by RocScience) was used. 


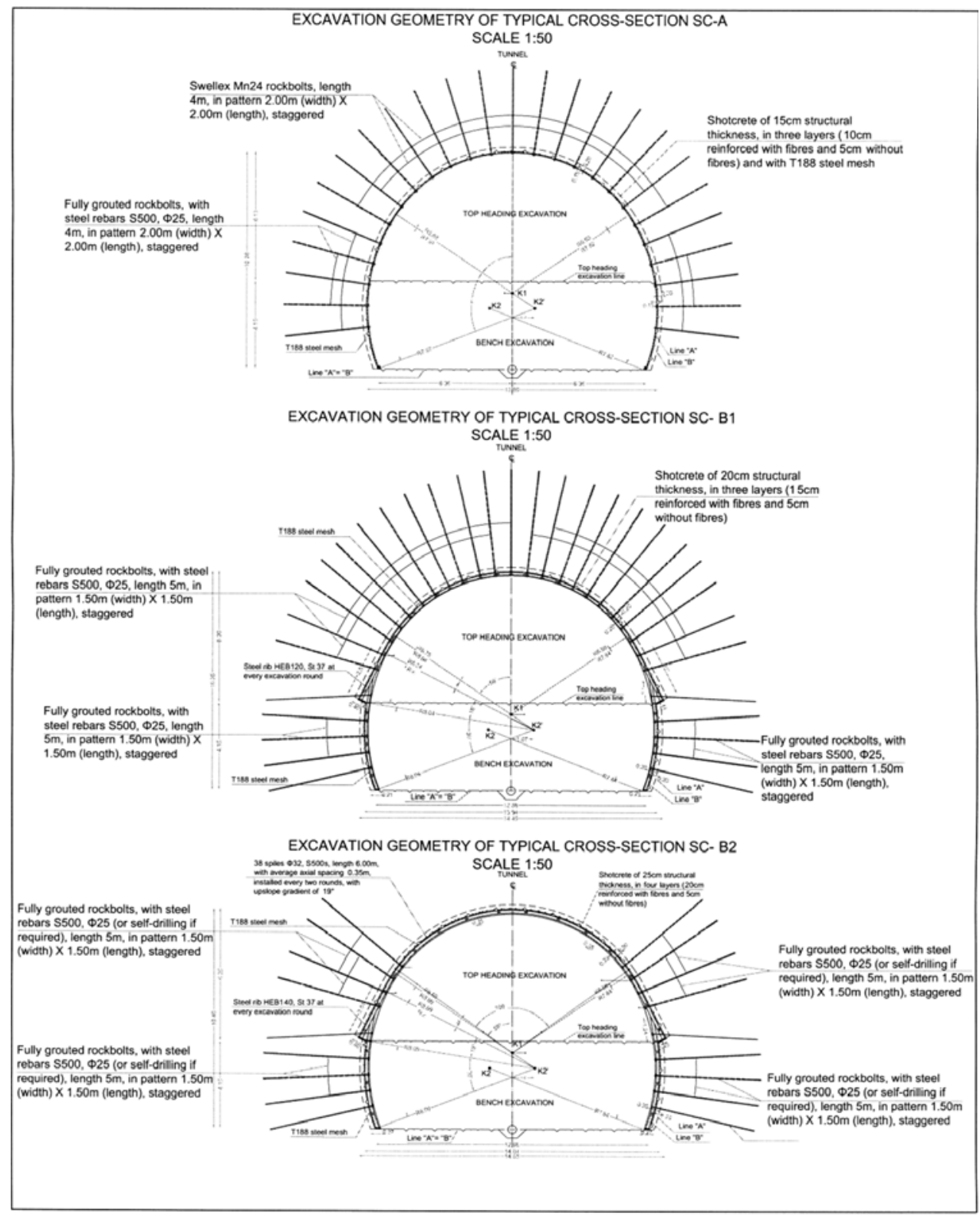

Fig. 5: Typical cross-section SC-A, SC-B1 and SC-B2 


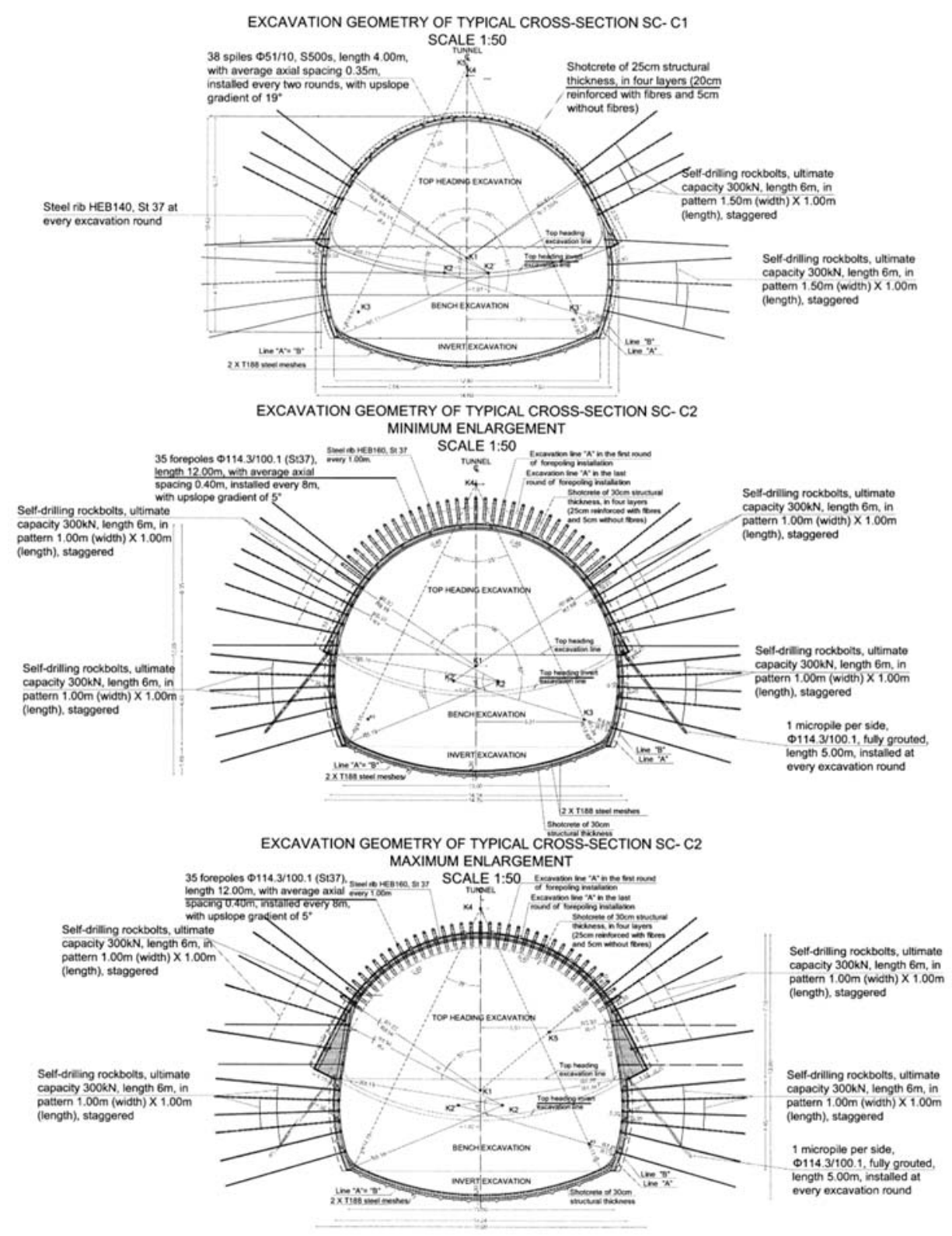

Fig. 6: Typical cross-section SC-C1 and SC-C2 
Table 4. Support measures of typical excavation and support cross-sections

\begin{tabular}{|c|c|c|c|c|c|}
\hline $\begin{array}{l}\text { Typical excavation and } \\
\text { support cross-sections }\end{array}$ & A & B1 & B2 & $\mathrm{C} 1$ & $\mathrm{C} 2$ \\
\hline $\begin{array}{c}\text { Shotcrete } \\
\text { (thickness in } \mathrm{cm} \text { ) }\end{array}$ & $15 \mathrm{~cm}$ & $20 \mathrm{~cm}$ & $25 \mathrm{~cm}$ & $25 \mathrm{~cm}$ & $30 \mathrm{~cm}$ \\
\hline $\begin{array}{c}\text { Rockbolts } \\
\text { (type - length in m) }\end{array}$ & $\begin{array}{l}\text { Swellex } \\
\text { MN24 - } \\
\varnothing 25 / \mathrm{S} 500 \\
(\mathrm{~L}=4 \mathrm{~m})\end{array}$ & $\begin{array}{c}\varnothing 25 / \mathrm{S} 500 \\
(\mathrm{~L}=5 \mathrm{~m})\end{array}$ & $\begin{array}{c}\varnothing 25 / \mathrm{S} 500 \text { or } \\
\text { Self-drilling } \\
(\mathrm{L}=5 \mathrm{~m})\end{array}$ & $\begin{array}{l}\text { Self-drilling } \\
\quad(\mathrm{L}=6 \mathrm{~m})\end{array}$ & Self-drilling $(\mathrm{L}=6 \mathrm{~m})$ \\
\hline Steel rib & No & HEB 120 & HEB 140 & HEB 140 & HEB 160 \\
\hline $\begin{array}{c}\text { Elephant foot } \\
\text { (thickness in } \mathrm{cm} \text { ) }\end{array}$ & No & $40 \mathrm{~cm}$ & $40 \mathrm{~cm}$ & $40 \mathrm{~cm}$ & $40 \varepsilon^{\prime} \omega \varsigma 115 \mathrm{~cm}$ \\
\hline $\begin{array}{l}\text { Face Shotcrete } \\
\text { (thickness in } \mathrm{cm} \text { ) }\end{array}$ & No & No & $0-5 \mathrm{~cm}$ & $5 \mathrm{~cm}$ & $5 \mathrm{~cm} / 10 \mathrm{~cm}$ \\
\hline Face core & No & No & No & No & Yes \\
\hline $\begin{array}{c}\text { Face dowels } \\
\text { Fiberglass (pieces) }\end{array}$ & No & No & $0-9$ & 9 & 16 \\
\hline Spiles or forepoles & No & No & $\begin{array}{l}\text { Spiles (38 } \\
\text { steel bars } \\
\varnothing 32-S t 37)\end{array}$ & $\begin{array}{l}\text { Spiles (38 steel } \\
\text { tubes } \Phi 51 / 10- \\
\text { St37) }\end{array}$ & $\begin{array}{l}\text { forepoles (35 steel } \\
\text { tubes } \Phi 114 / 100- \\
\text { St37) }\end{array}$ \\
\hline $\begin{array}{c}\text { Temporary (top-heading) } \\
\text { invert }\end{array}$ & No & No & No & Yes & Yes \\
\hline Final invert & No & No & No & Yes & Yes \\
\hline
\end{tabular}

The results of the above analyses were used for the assessment of the adequacy of the immediate support measures of each one of the five typical excavation and support cross-sections. The support measures of each one of the five typical excavation and support cross-sections are presented in Table 4.

Based on the results of the elasto-plastic, finite element stress analyses of the excavation and support models, for the examined combinations of typical excavation and support cross-sections, rockmass classes and overburden, the following conclusions were drawn

- The magnitude of expected convergence, as calculated for each one of the excavation stages, is limited for most cases within generally accepted levels. In particular for typical excavation and support cross-sections $\mathrm{A}, \mathrm{B} 1$ and $\mathrm{B} 2$, the estimated axial deformation is in the order of 1 to $2.5 \mathrm{~cm}$, for $\mathrm{C} 1$ in the order of 4 to $5 \mathrm{~cm}$ and for $\mathrm{C} 2$ in the order of 4.5 to $6.5 \mathrm{~cm}$

- The thickness of yield zone in the rockmass is relatively small (in the order of 1 to $3.5 \mathrm{~m}$ ) for typical excavation and support cross-sections A, B1 and B2 and intermediate to high (in the order of 4 to $41 \mathrm{~m}$ ) for typical excavation and support cross-sections $\mathrm{C} 1$ and $\mathrm{C} 2$. 
- Induced stresses in shotecrete are generally lower than its capacity, with rare excerptions, mainly at the joining area of top heading and temporary invert and the joining area of bench and final invert. Furthermore the percentage of yielded liner elements (used to model shotecrete) does not exceed $2 \%$.

- The induced forces on rockbolts installed at the perimeter of the excavation, are generally lower than the rockbolts' capacities. However, in some rare cases, the capacities of rockbolts are exceeded, but this does not affect the total stability of the underground excavation.

\section{Conclusions}

The heterogeneity of the ophiolites in the area is expressed by variable behaviour of the rockmass, from competent rock to very weak soil-like material, which in turn is responsible for the rapidly changing tunnelling conditions even in short distances. Furthermore, the groundwater level also varies significally, from below the redline, up to $31 \mathrm{~m}$ above it.

In order to cope with such rapidly changing tunnelling conditions, appropriate rockmass classes and corresponding support classes were adopted. The support classes utilise support measures ranging from light, for relatively good rockmass classes (e.g. A), to very heavy, for very poor rockmass classes (e.g. C1 and C2).

Finally, a relatively accurate estimation of the percentages of the Geotechnical units along the tunnels, as the one presented above, is of crucial importance for a successful tunnelling operation.

\section{References}

Bieniawski, Z.T. 1989. Engineering rock mass classifications. New York: Wiley.

Faulp P., Pavlopoulos A., Wagreich M. and Migiros G. 1996. Pre-Tertiary blueschist terrains in the Hellenides: evidence from detrital mineral of flysch successions. Terra Nova 9, 186-190.

Hoek, E., Carranza-Torres, C.T., and Corkum, B. 2002, Hoek-Brown failure criterion - 2002 edition. Proc. North American Rock Mechanics Society meeting in Toronto in July 2002

Hynes A.J, 1974. Igneous activity at the birth of ocean basin in eastern Greece. Canadian Journal of Earth Science 11, 842-853.

Smith A.G., Hynes A.J, Menzies M, Nisbet E.G., Price I., Welland M.J. and Ferriere J., 1975. The stratigraphy of the Orthis mountains, eastern central Greece: a deformed Mesozoic margin sequence. Eclogae.geol.Helv., 68/3, 463-481. 